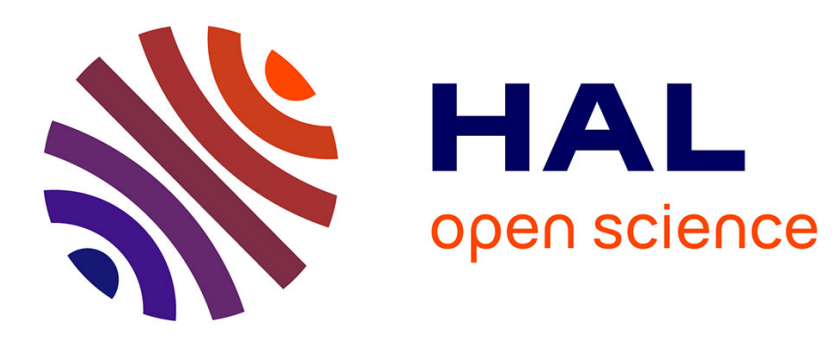

\title{
Ultra-High Temperature Ceramics : Developments for hypersonic applications
}

Jean-François Justin, Aurélie Julian-Jankowiak, Vincent Guérineau, Virginie Mathivet, Antoine Debarre

\section{To cite this version:}

Jean-François Justin, Aurélie Julian-Jankowiak, Vincent Guérineau, Virginie Mathivet, Antoine Debarre. Ultra-High Temperature Ceramics: Developments for hypersonic applications. HISST 2018, Nov 2018, MOSCOU, Russia. hal-01961007

\section{HAL Id: hal-01961007 https://hal.science/hal-01961007}

Submitted on 19 Dec 2018

HAL is a multi-disciplinary open access archive for the deposit and dissemination of scientific research documents, whether they are published or not. The documents may come from teaching and research institutions in France or abroad, or from public or private research centers.
L'archive ouverte pluridisciplinaire HAL, est destinée au dépôt et à la diffusion de documents scientifiques de niveau recherche, publiés ou non, émanant des établissements d'enseignement et de recherche français ou étrangers, des laboratoires publics ou privés. 


\title{
Ultra-High Temperature Ceramics : Developments for hypersonic applications
}

\author{
Jean-François Justin ${ }^{1}$, Aurélie Julian-Jankowiak², Vincent Guérineaư ${ }^{3}$, \\ Virginie Mathivet ${ }^{4}$, Antoine Debarre ${ }^{5}$
}

\begin{abstract}
Ultra-High Temperature Ceramics (UHTC) are good candidates to fulfil the harsh requirements of hypersonic applications. For more than a decade, ONERA has been actively involved in several programs to develop such materials for different applications (hypersonic flights, propulsion systems ...). In our laboratories, monolithic and composite materials have been investigated as well as several processing methods. In this paper, we present for example the $\mathrm{ZrB}_{2}-\mathrm{SiC}$ and $\mathrm{HfB}_{2}-\mathrm{SiC}$ compositions with $\mathrm{TaSi}_{2}$ or $\mathrm{Y}_{2} \mathrm{O}_{3}$ additions which have been especially studied in the European Projects ATLLAS and ATLLAS 2. Assessments of several prototypes in realistic environment are also described. Furthermore, based on these material developments, a specific study on the oxidation behaviour of such monoliths from $1200^{\circ} \mathrm{C}$ to $2400^{\circ} \mathrm{C}$ with a dedicated test bench using a $2 \mathrm{~kW} \mathrm{CO}$ laser has been carried out (oxidation under air and water vapour atmospheres). Recently, some work on the manufacturing of Ultra-High Temperature Ceramic Matrix Composites (UHTCMC) has been initiated using slurry infiltration and pyrolysis. The behaviour and properties of these materials are encouraging.
\end{abstract}

Keywords : Ultra-High Temperature Ceramics, Leading Edges, Injectors, CMC

\section{Nomenclature}

ATLLAS Aerodynamic and Thermal Load Interactions with Lightweight Advanced Materials for High Speed Flight

ATLLAS 2 Aero-Thermodynamic Loads on Lightweight Advanced Structures II

BLOX4 Banc Laser d'Oxydation $n^{\circ} 4$ ( $4^{\text {th }}$ laser oxidation analysis facility)

$\mathrm{C} / \mathrm{C}$-SiC Carbon fibre reinforced silicon carbide composite

CMC Ceramic Matrix Composite

CTE Coefficient of Thermal Expansion

EDM Electrical Discharge Machining

FAST Field Assisted Sintering Technology

HP Hot Pressing

PyC Pyrolytic Carbon

SiC Silicon Carbide

SIP Slurry Infiltration and Pyrolysis

UHTC Ultra-High Temperature Ceramics

UHTCMC Ultra-High Temperature Ceramic Matrix Composites

\footnotetext{
${ }^{1}$ ONERA / DMAS, Université Paris-Saclay, F-92322 Châtilllon, France, Jean-Francois.Justin@onera.fr,

2 ONERA / DMAS, Université Paris-Saclay, F-92322 Châtillon, France, Aurelie.Jankowiak@onera.fr,

3 ONERA / DMAS, Université Paris-Saclay, F-92322 Châtillon, France, Vincent.Guérineau@onera.fr,

${ }^{4}$ ONERA / DMAS, Université Paris-Saclay, F-92322 Châtillon, France, Virginie.Mathivet@onera.fr,

5 ONERA / DMAS, Université Paris-Saclay, F-92322 Châtillon, France, Antoine.Debarre@onera.fr.
} 


\section{Introduction}

Hypersonic flights, re-entry vehicles and propulsion applications all require new materials that can perform in oxidising or corrosive atmospheres at temperatures superior to $2000^{\circ} \mathrm{C}$ and sometimes over the course of a long working life. For re-entry vehicles and hypersonic aircraft, external parts like nose, vertical fins, wing leading edges or flaps are submitted to very high heat fluxes along the flight. Indeed, for hypersonic vehicles for example, performance improvement (lift-to-drag ratio in particular) requires slender aerodynamic shapes with sharp leading edges. However, the thinner the leading edge radius, the higher the temperature. These high heat fluxes are also present for some internal components used for hypersonic vehicle propulsion: injectors, vanes, engine inlets and exits, etc.

Several studies have revealed that Ultra High Temperature Ceramics were particularly interesting to fulfil these requirements [1-5]. UHTCs are compounds made of borides, carbides and nitrides such as $\mathrm{ZrB}_{2}, \mathrm{HfB}_{2}, \mathrm{ZrC}, \mathrm{HfC}, \mathrm{TaC}$, HfN which are characterised by high melting points (Table 1), high hardness, chemical inertness and relatively good resistance to oxidation in severe environments.

Table 1. Properties of some UHTCS

\begin{tabular}{ccc}
\hline Material & Density $\left(\mathbf{g} / \mathbf{c m}^{\mathbf{3}}\right)$ & $\begin{array}{c}\text { Melting } \\
\text { temperature }\left({ }^{\circ} \mathbf{C}\right)\end{array}$ \\
\hline $\mathrm{HfB}_{2}$ & 11.2 & 3380 \\
\hline $\mathrm{HfC}$ & 12.8 & 3900 \\
\hline $\mathrm{HfN}$ & 13.9 & 3385 \\
\hline $\mathrm{ZrB}{ }_{2}$ & 6.1 & 3245 \\
\hline $\mathrm{ZrC}$ & 6.6 & 3400 \\
\hline $\mathrm{ZrN}$ & 7.3 & 2950 \\
\hline $\mathrm{TiB} 2$ & 4.5 & 3225 \\
\hline $\mathrm{TiC}$ & 4.9 & 3100 \\
\hline $\mathrm{TiN}$ & 5.4 & 2950 \\
\hline $\mathrm{TaB}_{2}$ & 12.5 & 3040 \\
\hline $\mathrm{TaC}_{\mathrm{TaN}}$ & 14.5 & 3800 \\
\hline & 14.3 & 2700 \\
\hline
\end{tabular}

For a few years, the Materials and Structures Department of ONERA is involved in different projects concerning UHTC material developments from manufacturing to thermomechanical assessments of components in realistic environment and oxidation resistance understanding [6-12]. Most of our work on monolithic ceramics has been carried out on diborides of the group IVb ( $\mathrm{ZrB}_{2}$ and $\mathrm{HfB}_{2}$ ) which possess very high melting points $\left(>3200^{\circ} \mathrm{C}\right)$, excellent thermomechanical properties and a good resistance to oxidation when $\sim 20 \% \mathrm{vol}$. SiC is introduced as additive $[5,13]$. Moreover, in comparison with carbides and nitrides, diborides have also higher thermal and electrical conductivities, which give them a fairly good thermal shock resistance and a good machinability (by using EDM). This last point is appreciable for manufacturing complex shapes. However, the use of monolithic ceramics for high temperature structural applications is limited by some disadvantages (low fracture toughness notably). These issues explain the increasing interest for UHTC matrix composites (UHTCMCs) [1418]. As a consequence, our recent activities are more focused on continuous fibre reinforced composites in which carbides based compositions have been preferentially investigated ( $\mathrm{HfC}$ with $\mathrm{SiC}$ notably).

This paper presents a synthesis of the results collected on UHTC materials (monoliths and composites) in past and current studies. Several aspects are exposed and notably their manufacturing, their properties, their oxidation resistance, their assessment in realistic environments (arc-jet test, combustion chamber) ... 


\section{Materials manufacturing}

As mentioned previously, two main UHTC material families have been manufactured: monolithic ceramics and composites. Their properties are closely linked with the densification processes, compositions, starting raw materials, microstructures and so on.

\subsection{Monolithic ceramics}

$\mathrm{ZrB}_{2}-\mathrm{SiC}$ and $\mathrm{HfB}_{2}-\mathrm{SiC}$ compositions with or without additives have been selected for our studies. Additives as $\mathrm{TaSi}_{2}$ and $\mathrm{Y}_{2} \mathrm{O}_{3}$ were used firstly to make the sintering process easier and secondly to enhance oxidation resistance at high temperature. Commercially available $\mathrm{ZrB}_{2}, \mathrm{HfB}_{2}, \mathrm{SiC}, \mathrm{TaSi}_{2}$ and $\mathrm{Y}_{2} \mathrm{O}_{3}$ powders were employed to manufacture the materials (Table 2).

Table 2. Grade, purity, particle size and measured density of starting powders

\begin{tabular}{ccccc}
\hline Powder & Grade / Supplier & $\begin{array}{c}\text { Purity } \\
\mathbf{( \% )}\end{array}$ & $\begin{array}{c}\text { Particle size } \\
\mathbf{d}_{\mathbf{5 0}}(\boldsymbol{\mu m})\end{array}$ & Density \\
\hline $\mathrm{ZrB}_{2}$ & Z-1031 / Cerac & 99.5 & 8.2 & 5.97 \\
& Grade B / H.C Starck & $>97.8$ & 2.8 & 5.98 \\
\hline $\mathrm{HfB}_{2}$ & $\mathrm{H}-1002$ / Cerac & 99.5 & 2.0 & 10.85 \\
& Grade A / H.C Starck & $>97.0$ & 7.6 & 10.66 \\
\hline $\mathrm{SiC}$ & BF12 / H.C. Starck & $>98.5$ & 0.6 & 3.15 \\
\hline $\mathrm{TaSi}_{2}$ & T-1016 / Cerac & 99.5 & 6.5 & 9.02 \\
\hline $\mathrm{Y}_{2} \mathrm{O}_{3}$ & Ampere Industrie & 99.99 & $<5.0$ & 4.89 \\
\hline
\end{tabular}

To obtain the selected compositions, starting powders were weighed according to their respective proportions and attrition milled in cyclohexane using $\mathrm{ZrO}_{2}$ or WC media. Then, the mixtures were dried in a rotary evaporator and sieved down to $50 \mu \mathrm{m}$ mesh size to avoid agglomeration. Finally, the powder blends were sintered in coated graphite dies (Papyex $\left.{ }^{\circledR}+\mathrm{BN}\right)$ by two different processes :

- Hot Pressing (HP) at Onera,

- Field Assisted Sintering Technology (FAST) also known as Spark Plasma Sintering (SPS) at ICB in Dijon (FCT System Gmbh, HP D 125) and Mateis in Lyon (FCT System Gmbh, HP D 25).

$\mathrm{ZrB}_{2}, \mathrm{HfB}_{2}$ and $\mathrm{TaSi}_{2}$ powders from Cerac were used only for HPed samples. A synthesis of the sintering parameters of some studied compositions is reported in Table 3.

Table 3. Sintering parameters of several monolithic samples

\begin{tabular}{|c|c|c|c|c|}
\hline Method & $\begin{array}{l}\text { Sample } \\
\text { size }\end{array}$ & Composition & Reference & Sintering parameters \\
\hline $\begin{array}{c}\text { HP } \\
\text { (Onera) }\end{array}$ & $\begin{array}{l}68 \times 68 \mathrm{~mm}^{2} \\
\text { plates } \\
\text { (maximum) }\end{array}$ & $\begin{array}{l}\mathrm{ZrB}_{2} / 20 \mathrm{vol} \% \mathrm{SiC} / 20 \mathrm{vol}_{\%} \mathrm{TaSi}_{2} \\
\mathrm{HfB}_{2} / 20 \mathrm{vol} \% \mathrm{SiC} / 20 \mathrm{vol}_{2} \mathrm{TaSi}_{2} \\
\mathrm{ZrB}_{2} / 20 \mathrm{vol} \% \mathrm{SiC}\end{array}$ & & $\begin{array}{l}1700^{\circ} \mathrm{C} / 120 \mathrm{~min} / 27 \mathrm{MPa} / \text { Argon } \\
1800^{\circ} \mathrm{C} / 120 \mathrm{~min} / 27 \mathrm{MPa} / \text { Argon } \\
1800^{\circ} \mathrm{C} / 120 \mathrm{~min} / 27 \mathrm{MPa} / \text { Argon }\end{array}$ \\
\hline $\begin{array}{c}\text { FAST } \\
\text { (Mateis) }\end{array}$ & $\begin{array}{c}\varnothing 20 \mathrm{~mm} \\
\text { discs }\end{array}$ & $\begin{array}{l}\mathrm{ZrB} / 20 \mathrm{vol} \% \mathrm{SiC} \\
\mathrm{HfB}_{2} / 20 \mathrm{vol} \% \mathrm{SiC} \\
\mathrm{HfB}_{2} / 20 \mathrm{vol} \% \mathrm{SiC} / 3 \text { vol\% } \mathrm{Y}_{2} \mathrm{O}_{3}\end{array}$ & $\begin{array}{l}\text { ZS-FAST1 } \\
\text { HS-FAST1 } \\
\text { HSY-FAST1 }\end{array}$ & $\begin{array}{l}2100^{\circ} \mathrm{C} / 5 \mathrm{~min} / 7 \mathrm{MPa} / \text { Argon } \\
2000^{\circ} \mathrm{C} / 5 \mathrm{~min} / 7 \mathrm{MPa} / \text { Argon } \\
1880^{\circ} \mathrm{C} / 5 \mathrm{~min} / 7 \mathrm{MPa} / \text { Argon }\end{array}$ \\
\hline $\begin{array}{l}\text { FAST } \\
\text { (ICB) }\end{array}$ & $\begin{array}{c}\varnothing 60 \mathrm{~mm} \\
\text { discs } \\
\text { (maximum) }\end{array}$ & $\begin{array}{l}\mathrm{ZrB}_{2} / 7.5 \mathrm{vol} \% \mathrm{SiC} \\
\mathrm{HfB}_{2} / 20 \mathrm{vol} \% \mathrm{SiC} \\
\mathrm{HfB}_{2} / 20 \mathrm{vol} \% \mathrm{SiC} / 3 \mathrm{vol} \% \mathrm{Y}_{2} \mathrm{O}_{3}\end{array}$ & $\begin{array}{l}\text { ZS-FAST2 } \\
\text { HS-FAST2 } \\
\text { HSY-FAST2 }\end{array}$ & $\begin{array}{l}2100^{\circ} \mathrm{C} / 15 \mathrm{~min} / 50 \mathrm{MPa} / \text { vacuum } \\
2100^{\circ} \mathrm{C} / 15 \mathrm{~min} / 28 \mathrm{MPa} / \text { vacuum } \\
2000^{\circ} \mathrm{C} / 15 \mathrm{~min} / 28 \mathrm{MPa} / \text { vacuum }\end{array}$ \\
\hline
\end{tabular}

The FAST has the advantage of carrying out compaction, sintering and cooling with high temperature ramps $\left(50^{\circ} \mathrm{C} / \mathrm{min}\right.$ or $100^{\circ} \mathrm{C} / \mathrm{min}$ in these studies to be compared with $10^{\circ} \mathrm{C} / \mathrm{min}$ for $\left.\mathrm{HP}\right)$. 


\subsection{UHTC Composites}

For UHTC composites (UHTCMC), as previously mentioned, materials based on carbides matrix reinforced with continuous carbon fibres have been preferentially investigated $\left(\mathrm{C}_{\mathrm{f}} / \mathrm{HfC}-20 \mathrm{vol} \% \mathrm{SiC}\right.$ in particular). The selected process to obtain these composites was a pressure-assisted Slurry Infiltration and Pyrolysis (SIP) method [19-20.]. This process involves infiltration of a "low-viscosity" slurry into a fibrous preform followed by pyrolysis to obtain the ceramic matrix.

The selected raw materials for these composites were a 2D carbon fibre fabric (Toho Tenax HTA5131, $3 \mathrm{~K}$, twill weave $2 \times 2,282 \mathrm{~g} / \mathrm{m}^{2}$ ) for the reinforcement and a combination of $\mathrm{HfC}$ powder (H.C. Starck, $\mathrm{d}_{50}=1.95 \mu \mathrm{m}, 12.2 \mathrm{~g} / \mathrm{cm}^{3}$ ) plus SiC precursor (Starfire Systems SMP-10 ) for the matrix. In order to correctly infiltrate the $\mathrm{C}$ preform, the attention has been focused on the optimisation of the slurry to obtain a high solid content ( $>50$ vol. $\%$ ) as well as a low viscosity ( $<150 \mathrm{mPa} . \mathrm{s})$. Several infiltration procedures have been investigated : one step method (powder + precursor in the same slurry) or multi-step method (powder first and precursor after). For the infiltration phase, a specific metallic mould $\left(40 \times 50 \mathrm{~mm}^{2}\right)$ has been used to place the carbon plies and set the final plate thickness ( 6 plies for $\sim 2 \mathrm{~mm} / \mathrm{V}_{\mathrm{f}}>40$ vol. $\%$ of the mould cavity). The infiltration is realised by applying vacuum on one side of the mould in order to suck the slurry located in a recipient connected to the other side of the assembly. The experiment is stopped when the slurry is seen on the side under vacuum.

After infiltration, samples are dried and hot pressed in graphite die (at $1600^{\circ} \mathrm{C} / 24 \mathrm{MPa} / 1 \mathrm{~h}$ ) under flowing argon to fully transform the precursor in crystalline SiC.

\section{Materials characterisation}

Concerning the UHTC monoliths notably, a thorough characterisation of their properties has been achieved in several studies and in particular in the European Projects ATLLAS and ATLLAS 2 [10]. Several aspects have been studied: microstructure (X-Ray diffraction), chemical, physical, mechanical, thermal and optical properties (diffusivity, heat capacity, CTE, emissivity), machining behaviour, oxidation resistance in severe environment etc. Only a few of these data are reported in this paper. The bulk density and open porosity of materials were measured by the Archimedes' method. The level of densification was calculated as the ratio of the apparent density on the theoretical density. Microstructures were observed on polished cross-sections using a Scanning Electron Microscope (SEM) equipped with energy dispersive spectroscopy (EDS) for local analysis. Bending flexural strength has been determined by three point flexural tests (test speed $0.3 \mathrm{~mm} / \mathrm{min}$, span of $30 \mathrm{~mm}$ ). Young's moduli were measured by impulse excitation of vibration on bars $\left(\sim 35.1 \times 5.2 \times 2.1 \mathrm{~mm}^{3}\right)$ using a Grindosonic MK5 apparatus [21]. Hardness (Hv) and fracture toughness ( $\mathrm{K}_{\mathrm{IC}}$ ) were obtained on $1 / 4 \mu \mathrm{m}$ polished surfaces by Vickers' indentation with a load of $98 \mathrm{~N}$. The fracture toughness $\left(\mathrm{K}_{\mathrm{IC}}\right)$ is estimated by crack length measurement of the radial crack pattern formed around Vickers indents [22]. Thermal expansion coefficient were determined up to $1440^{\circ} \mathrm{C}$ with a heating rate ${ }^{\circ} \mathrm{C} / \mathrm{min}$ under flowing argon $(20 \mathrm{ml} / \mathrm{min})$ using a SETSYS Evolution SETARAM dilatometer. The oxidation behaviour was studied from $1200^{\circ} \mathrm{C}$ to $2400^{\circ} \mathrm{C}$ with a specific test bench using a $2 \mathrm{~kW} \mathrm{CO}$ laser under air and water vapour atmospheres.

\subsection{Monolithic ceramics properties}

\subsubsection{Microstructure}

Densification levels measured on all types of monoliths are superior to $96 \%$ of the theoretical density and open porosities lower than $1 \%$. Microstructural aspects of these materials after HP or FAST are presented in Fig 1 and Fig 2. We can see that very fine microstructures are obtained with a good homogeneity and a small grain size. A finer microstructure is observed for $\mathrm{TaSi}_{2}$-containing materials due to a lower sintering temperature but also to the fact that this compound can act as a grain growth inhibitor. 

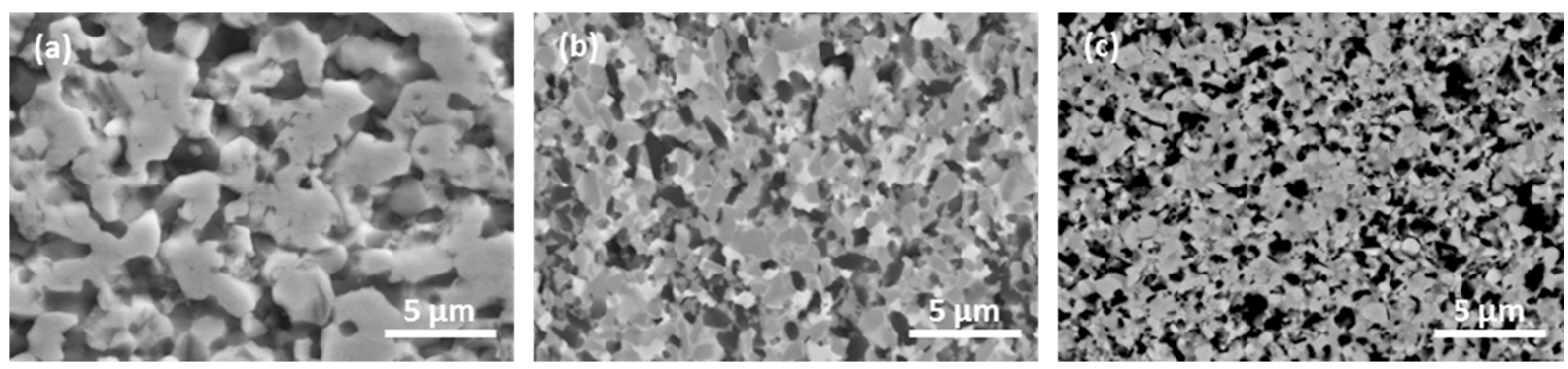

Fig 1. SEM micrographs of (a) $\mathrm{ZrB}_{2} / 20$ vol.\%. SiC , (b) $\mathrm{ZrB}_{2} / 20$ vol.\%. SiC/20 vol.\% $\mathrm{TaSi}_{2}$ and (c) $\mathrm{HfB}_{2} / 20$ vol. $\%$. SiC/20 vol. $\% \mathrm{TaSi}_{2}$ monoliths densified by HP

(in grey, $\mathrm{ZrB}_{2}$ or $\mathrm{HfB}_{2}$; in black, $\mathrm{SiC}$; in white, $\mathrm{TaSi}_{2}$ )
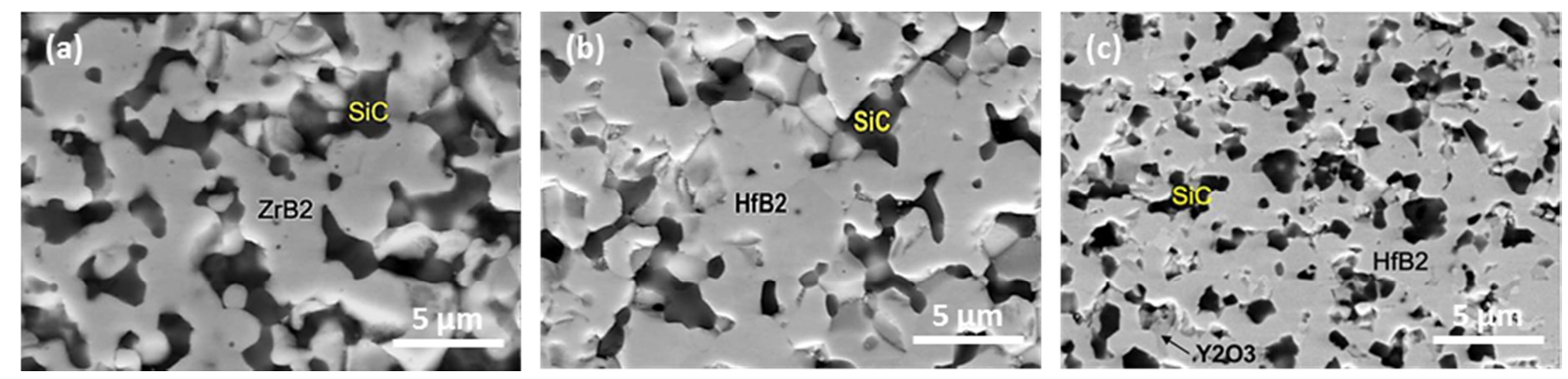

Fig 2. SEM micrographs of (a) $\mathrm{ZrB}_{2} / 20$ vol.\%. SiC , (b) $\mathrm{HfB}_{2} / 20$ vol.\%. SiC and (c) $\mathrm{HfB}_{2} / 20$ vol.\%. SiC/3 vol. $\% \mathrm{Y}_{2} \mathrm{O}_{3}$ monoliths densified by FAST

\subsubsection{Mechanical behaviour}

Mechanical properties, at room temperature, of several monolithic samples are reported in Table 4. The mechanical behaviour of these monoliths is really satisfactory. Moreover, it is important to notice than at high temperature some of these properties are sometimes even higher (flexural strength in particular) [7].

Table 4. Density, Young's Modulus, bending flexural strength, fracture toughness, hardness and coefficient of thermal expansion of materials sintered by HP and FAST.

\begin{tabular}{|c|c|c|c|c|c|c|}
\hline $\begin{array}{l}\text { Monolith } \\
\text { reference }\end{array}$ & $\begin{array}{c}\rho \\
\left(\mathrm{g} / \mathrm{cm}^{3}\right)\end{array}$ & $\begin{array}{c}E \\
(\mathrm{GPa})\end{array}$ & $\begin{array}{c}\sigma_{\mathrm{f}} \\
(\mathrm{MPa})\end{array}$ & $\begin{array}{c}\mathrm{K}_{1 \mathrm{C}} \\
\left(\mathrm{MPa} \cdot \mathrm{m}^{1 / 2}\right)\end{array}$ & $\begin{array}{c}\mathbf{H}_{\mathrm{v}} \\
(\mathrm{GPa})\end{array}$ & $\begin{array}{c}\text { CTE } \\
\left(.10^{-6}{ }^{\circ} \mathrm{C}^{-1}\right)\end{array}$ \\
\hline ZST-HP & 5,95 & $446 \pm 9$ & $688 \pm 79$ & $4,4 \pm 0,3$ & $18,1 \pm 0,4$ & $7,3\left(25-1300^{\circ} \mathrm{C}\right)$ \\
\hline HST-HP & 9,09 & $498 \pm 6$ & $869 \pm 170$ & $4,6 \pm 0,2$ & $18,1 \pm 0,6$ & $7,4\left(25-1300^{\circ} \mathrm{C}\right)$ \\
\hline ZS-HP & 5,36 & $465 \pm 15$ & $451 \pm 90$ & $4,3 \pm 0,2$ & $20,9 \pm 1,9$ & $7,2\left(25-1300^{\circ} \mathrm{C}\right)$ \\
\hline ZS-FAST1 & 5,32 & -- & $468 \pm 147 *$ & $3,5 \pm 0,7$ & $15,3 \pm 0,6$ & $7,8\left(25-1440^{\circ} \mathrm{C}\right)$ \\
\hline ZS-FAST2 & 5,65 & $416 \pm 3$ & $584 \pm 82$ & -- & -- & $7,7\left(25-1440^{\circ} \mathrm{C}\right)$ \\
\hline HS-FAST2 & 9,19 & $479 \pm 11$ & $694 \pm 91$ & $6,7 \pm 0,9$ & $17,5 \pm 0,3$ & $7,4\left(25-1440^{\circ} \mathrm{C}\right)$ \\
\hline HSY-FAST2 & 9,04 & $489 \pm 4$ & $843 \pm 110$ & $3,9 \pm 0,3$ & $21,9 \pm 1,1$ & $7,5\left(25-1440^{\circ} \mathrm{C}\right)$ \\
\hline
\end{tabular}

*bi-axial flexural strength

Globally, these materials exhibit interesting mechanical properties and they have been applied to manufacture prototypes and realistic components which have been tested (see § 4). However, regarding the fracture toughness of these monolithic ceramics, as predicted they are quite low and similar to that of common silicon nitride $\left(\mathrm{K}_{1 \mathrm{C}} \sim 3.5-6 \mathrm{MPa} \cdot \mathrm{m}^{1 / 2}\right)$. Thus, as already mentioned, in order to equally dispose of materials with higher toughness levels, a good part of the recent work has been oriented on UHTCMC. These composites could be associated later with other materials to be able to design new components. 


\subsubsection{Oxidation resistance}

Since the first ATTLAS project, several test campaigns have been carried out in order to investigate the thermal and chemical resistance of the monoliths. Most of them were fulfilled with a home-made device (BLOX4) but also in more realistic conditions (close to hypersonic flight for example see § 4). BLOX4 is a facility used for oxidation tests at very high temperatures (up to $2500^{\circ} \mathrm{C}$ ) in controlled atmospheres $\left(\mathrm{H}_{2} \mathrm{O}, \mathrm{Ar}, \mathrm{N}_{2}, \mathrm{H}_{2}\right.$, air ...) at pressures ranging from few millibars to 4 bar. Heating of discs samples is ensured thanks to a $\mathrm{CO}_{2}$ laser $(2 \mathrm{~kW})$. Surface temperature of the monoliths is measured with two bicolor pyrometers. A schematic view of this device as well as a $\varnothing 20 \mathrm{~mm}$ disc sample $\left(\mathrm{HfB}_{2} / 20 \mathrm{vol} \% \mathrm{SiC} / 3 \mathrm{vol} \% \mathrm{Y}_{2} \mathrm{O}_{3}\right)$ before and during a test at $1800^{\circ} \mathrm{C}$ is presented in Fig 3.

In the framework of a recent PhD work three compositions densified by FAST, previously investigated in ATTLAS projects, have been specifically studied at very high temperature under oxidative atmosphere [11-12] :

- $\mathrm{ZrB}_{2} / 20 \mathrm{vol} \% \mathrm{SiC}$ (labelled ZS-FAST1 or only ZS),

- $\mathrm{HfB}_{2} / 20 \mathrm{vol} \% \mathrm{SiC}$ (labelled HS-FAST1 or only HS),

- $\mathrm{HfB}_{2} / 20 \mathrm{vol} \% \mathrm{SiC} / 3 \mathrm{vol} \% \mathrm{Y}_{2} \mathrm{O}_{3}$ (labelled HSY-FAST1 or only HSY).

In this work, all the tests were carried out at a total pressure of 1 bar, under an $\mathrm{H}_{2} \mathrm{O} / \mathrm{Ar}$ atmosphere (30/70 vol\% in Standard Liter). During these tests, once $1000^{\circ} \mathrm{C}$ is reached (laser power ramp), a temperature ramp of $5^{\circ} \mathrm{C} / \mathrm{s}$ is imposed, allowing the sample to reach the target temperature (between 1200 and $2400^{\circ} \mathrm{C}$ ) where a dwell time is applied before the temperature decrease at the same rate.
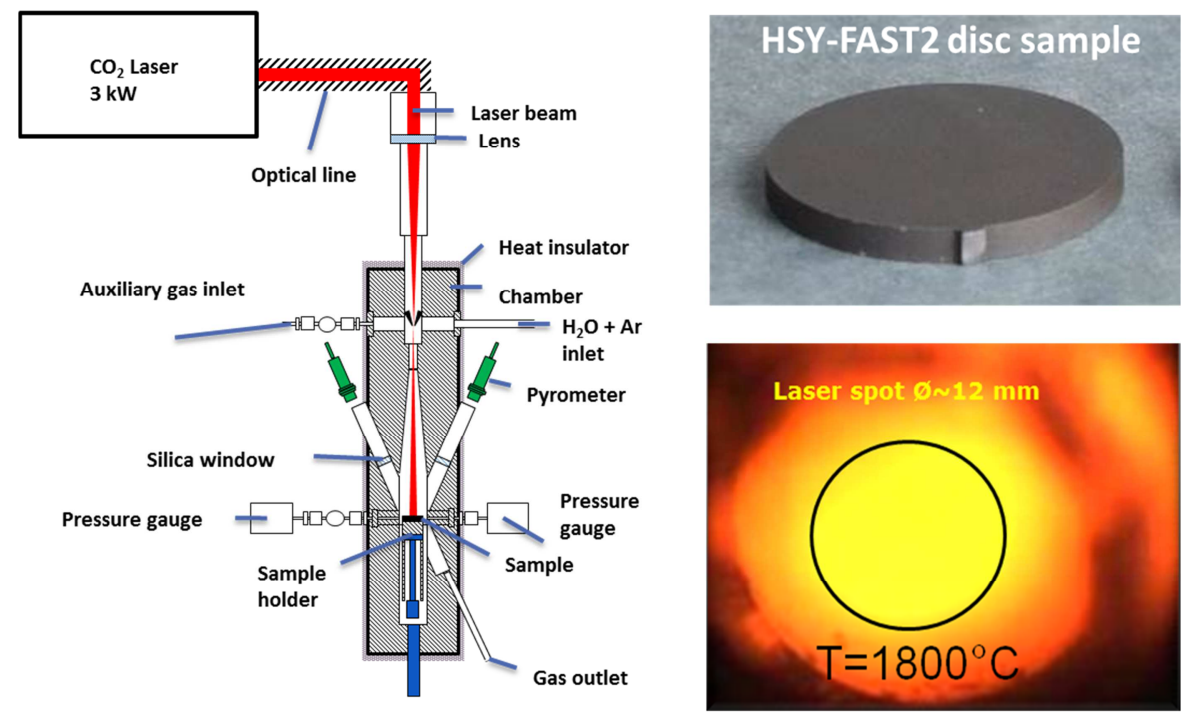

Fig 3. Schematic representation of the BLOX4 device, disc sample after machining and surface visualisation during a test at $1800^{\circ} \mathrm{C}$

The behaviour of these compositions is greatly dependant of the test temperature. For a dwell time of $20 \mathrm{~s}$ we have noticed the following results. Below $1500^{\circ} \mathrm{C}$, very thin oxidised layers are formed (according to the initial composition, monoclinic $\mathrm{HfO}_{2}$ or $\mathrm{ZrO}_{2}$ ). At $1550^{\circ} \mathrm{C}, \mathrm{ZS}, \mathrm{HS}$ and $\mathrm{HSY}$ exhibit a two-layered oxide scale made of a glassy $\mathrm{SiO}_{2}$ rich layer on the top and beneath an $\mathrm{HfO}_{2}$ or $\mathrm{ZrO}_{2}$ layer. At $1900^{\circ} \mathrm{C}$, a three-layered oxide scale is observed for all the compositions: a heterogeneously distributed glassy silica rich layer on the top, an $\mathrm{HfO}_{2}$ or $\mathrm{ZrO}_{2}$ layer and then a SiC-depleted $\mathrm{HfB}_{2}$ or $\mathrm{ZrB}_{2}$ layer. Moreover, some mechanical damages (non-cohesive lamellae) are observed on materials that do not contain $\mathrm{Y}_{2} \mathrm{O}_{3}$. At $2200^{\circ} \mathrm{C}$, some mechanical issues are detected for ZS samples and a nonadherent oxide layer is present on HS. However, for HSY, oxide layers are still adherent even though the top $\mathrm{HfO}_{2}$ layer contains cracks. This good behaviour is due firstly to the monoclinic to tetragonal transition of $\mathrm{HfO}_{2}$ which is less preponderant in HSY than in $\mathrm{HS}$ and secondly to the creation of an $\mathrm{Y}_{2} \mathrm{Si}_{2} \mathrm{O}_{7}$ interphase (between $\mathrm{HfO}_{2}$ and the $\mathrm{SiC}$-depleted $\mathrm{HfB}_{2}$ layer) that mitigates the thermal mismatch. At $2400^{\circ} \mathrm{C}$, only HS has been investigated. For this composition, despite some mechanical damages, the $\mathrm{HfO}_{2}$ top layer exhibits evidence of sintering and might provide further resistance towards oxidation. 


\subsection{UHTC Composites properties}

It is important to notice that for these materials the development phase is in progress and that several adjustments, on the composition and on the process, are always done. For example, a preliminary work on a PyC fibre/matrix interphase has been carried out (not exposed in this paper). As a consequence, microstructures which are presented in this paragraph (Fig 4) are representative of two types of composites $\left(\mathrm{C}_{\mathrm{f}} / \mathrm{HfC}-20 \mathrm{vol}\right.$. \% SiC) manufactured differently according to the information previously mentioned (§2.2). One infiltration step has been applied for the labelled "Composite A" and two for the "Composite B".

Both composites exhibit a fairly good matrix distribution between the plies however the infiltration process seems still imperfect. Moreover, a few voids and some small cracks are also visible. In fact, some yarns are not completely infiltrated by the slurry and notably their centres. Thus, despite the small grain size of the HfC powder, we can observe a partial filtration of the suspension by the fibres. It is not the case for the $\mathrm{SiC}$ precursor which is sufficiently liquid during the infiltration process to correctly penetrate inside the fibre tows. On the other hand, with the thermal treatment applied for densification and pyrolysis, there is no reaction occurring at the fibre/matrix interface which is a good point for further developments.
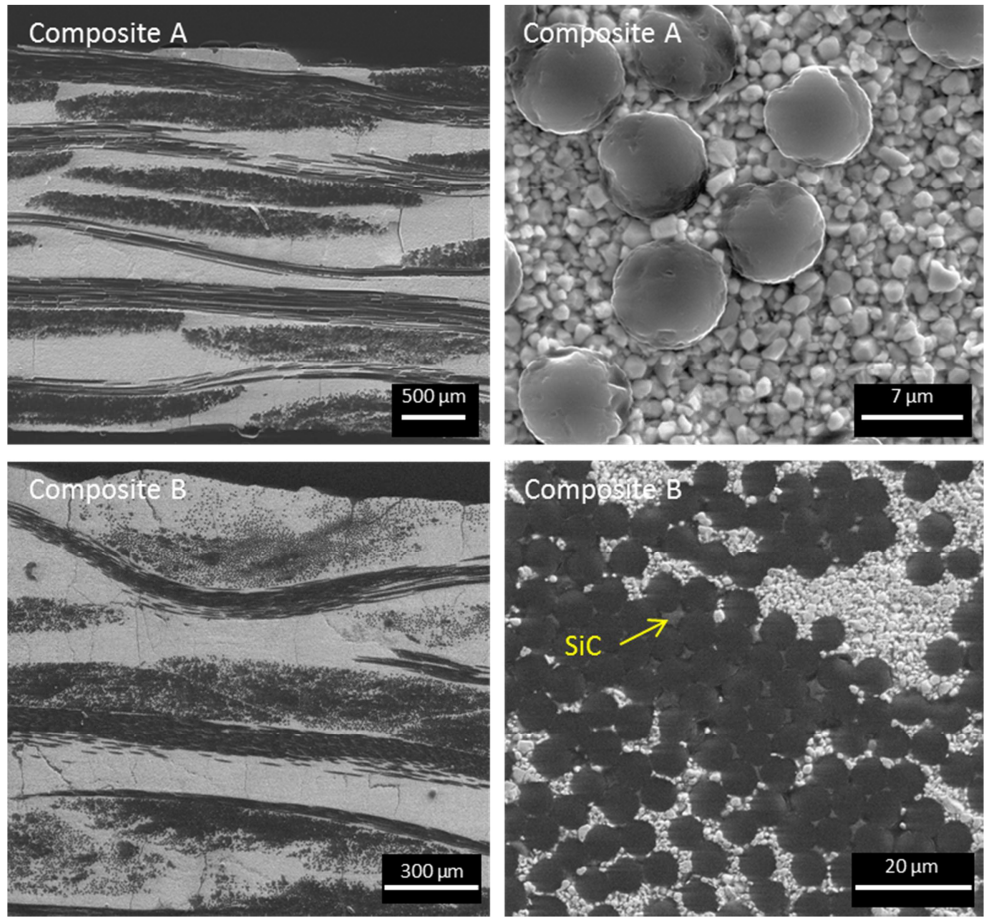

Fig 4. Microstructure of two Cf/HfC-SiC composites made by SIP

Several UHTCMC have been manufactured during this first development phase. For these materials, final density values are distributed between 5 and 6 . No macro-pores are observed and the porosity is principally composed of small voids and cracks. However, the open porosity level is still important (between 21 and 29 vol. \%) for a fibre fraction estimated between 30 and 43 vol. \%.

Given the results, it is evident that some further work is necessary to optimise the densification step (several infiltrations, new infiltrations parameters, finer grain size ...). Indeed, this is the key to improve the mechanical properties : Young's moduli are around $50 \mathrm{GPa}$ and bending flexural strength around $70 \mathrm{MPa}$.

Thus the development phase is always in progress in order to increase performances.

\section{Realisations and tests in realistic environments}

During the development on UHTC monoliths and in particular in ATLLAS projects, we have had the opportunity to assess the materials in diverse facilities to determine their performance. The goal was to test them in more and more representative conditions of a real application. The two most pertinent assessments carried out are exposed below. 


\subsection{Arc-jet tests}

In the first ATLLAS program, a test campaign was carried out under high-enthalpy hypersonic flow in an arc-jet facility of DLR Cologne (L2K) with the support of B. Esser [23]. For each composition sintered by HP (ZS-HP, ZST-HP and HST-HP), four disc-shaped samples ( $\varnothing 26.5 \mathrm{~mm}$, e $=4 \mathrm{~mm}$ ) were assayed between 1100 and $1500^{\circ} \mathrm{C}$ for cumulated duration up to $900 \mathrm{~s}$ (Fig 5). The resistance of the samples to high enthalpy flow was assessed by several measurements and analysis (weighing, thickness checking, SEM observations ...).
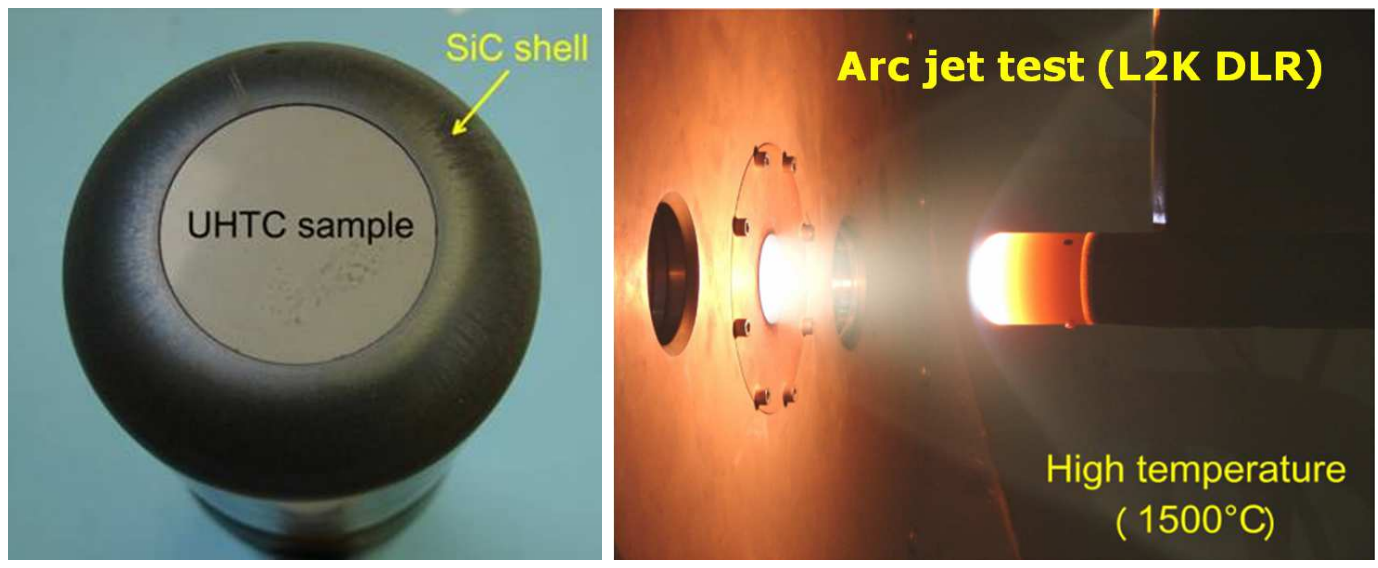

Fig 5. $\varnothing 26.5 \mathrm{~mm}$ UHTC sample holder and flow field around sample holder during a test at $1500^{\circ} \mathrm{C}$

The results of this test campaign were very satisfactory. All the monolithic materials are able to sustain high thermal loads (up to $1500^{\circ} \mathrm{C} / 600 \mathrm{~s}$ ). For each test condition, good material resistance was observed (extremely low mass and thickness variations notably). At $1500^{\circ} \mathrm{C}$ for example, UHTC samples exhibited a two-layered scale made of a thin protective glassy $\mathrm{SiO}_{2}$ rich layer on the top and underneath an intermediate layer in the process of being oxidised (SiC-depleted layer). Thus cumulative durations up to $900 \mathrm{~s}$ were performed without any problems (for all the selected compositions). A very good sample-to-sample reproducibility and a lack of sensitivity to thermal load cycling have been demonstrated.

As a consequence of the good results obtained in this program, the development has been pushed forward in the ATLLAS 2 project in order to design, manufacture and test uncooled injectors for ramjet engine.

\subsection{Uncooled injectors in a ramjet combustor}

The main goal of developing UHTC uncooled fin injectors is to ensure a better propulsive efficiency in ramjet engine. During the ATLLAS 2 program, in parallel with a development phase dedicated to UHTC monoliths sintered by FAST (ZS-FAST2, HS-FAST2 and HSY-FAST2), a work has been accomplished in order to define an adequate design for this injectors based on a generic rhombusshaped injection strut with dimensions around $40 \mathrm{~mm}$ in length and $20 \mathrm{~mm}$ in height. Injectors were required to contain a fuel feed which should exit at two portholes at the strut's downstream region. The final objective of this work was to validate this uncooled concept in relevant environment (Mach 6 air-breathing flight with stoichiometric combustion) in a MBDA facility (SMR dual-mode ramjet combustion chamber METHYLE) [24].

The first idea was to manufacture injectors made of two components linked via a sliding connection : an upper part in UHTC directly in the flux (injector) and a lower part in CMC connected to the metallic chamber wall (basis). However, due to difficulties during the machining step on UHTC monoliths, an alternative design has been finally selected. This hybrid design was less difficult to realise. It was also made of two components : a leading edge of $1 \mathrm{~mm}$ radius in UHTC placed in front of the flux and a basis in CMC for the lower part and also for the rear upper part of the injector. An important advantage of this hybrid design was to avoid the passage of the fuel injection tube in two different materials which would imply a perfect control of the tightness between the CMC and the UHTC parts. Some schematic representations of this concept are presented in Fig 6 . We can notice than a specific 
design of the bottom of the CMC has also been done by the DLR to connect the assembly to the METHYLE test bench.
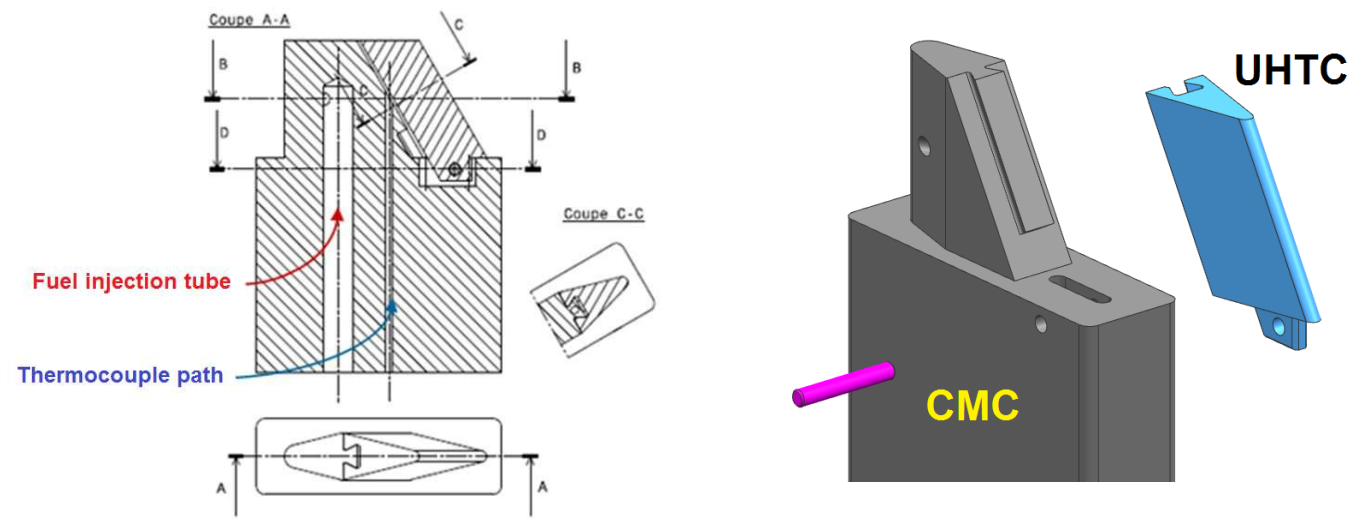

Fig 6. Schematic representations of the hybrid design selected for the UHTC uncooled fin injector

According to the previous design, two types of hybrid injectors have been manufactured for the test phase: one with an UHTC leading edge made from a HS-FAST2 monolith and another one machined from a HSY-FAST2 monolith. CMC basis of same nature were used for both types of injectors: a C/C$\mathrm{SiC}$ provided and machined by the DLR. As planned, the test campaign has been performed with the MBDA facility to simulate a long duration flight at Mach 6 (Fig 7). During this campaign, hybrid injectors presented in this paragraph but also other injector concepts based on CMC were investigated [9]. The fuel injected through the assembly was a gaseous mixture of $\mathrm{H}_{2}$ and $\mathrm{CH}_{4}$ $(20 / 80 \%)$ with an equivalence ratio of 1.0 . This corresponded to a mass flow of $12 \mathrm{~g} / \mathrm{s}$ for each strut injector. The incoming air had a recovery temperature of about $1600 \mathrm{~K}$, and no cooling by radiation was possible thanks to a thermal barrier coating on the walls.

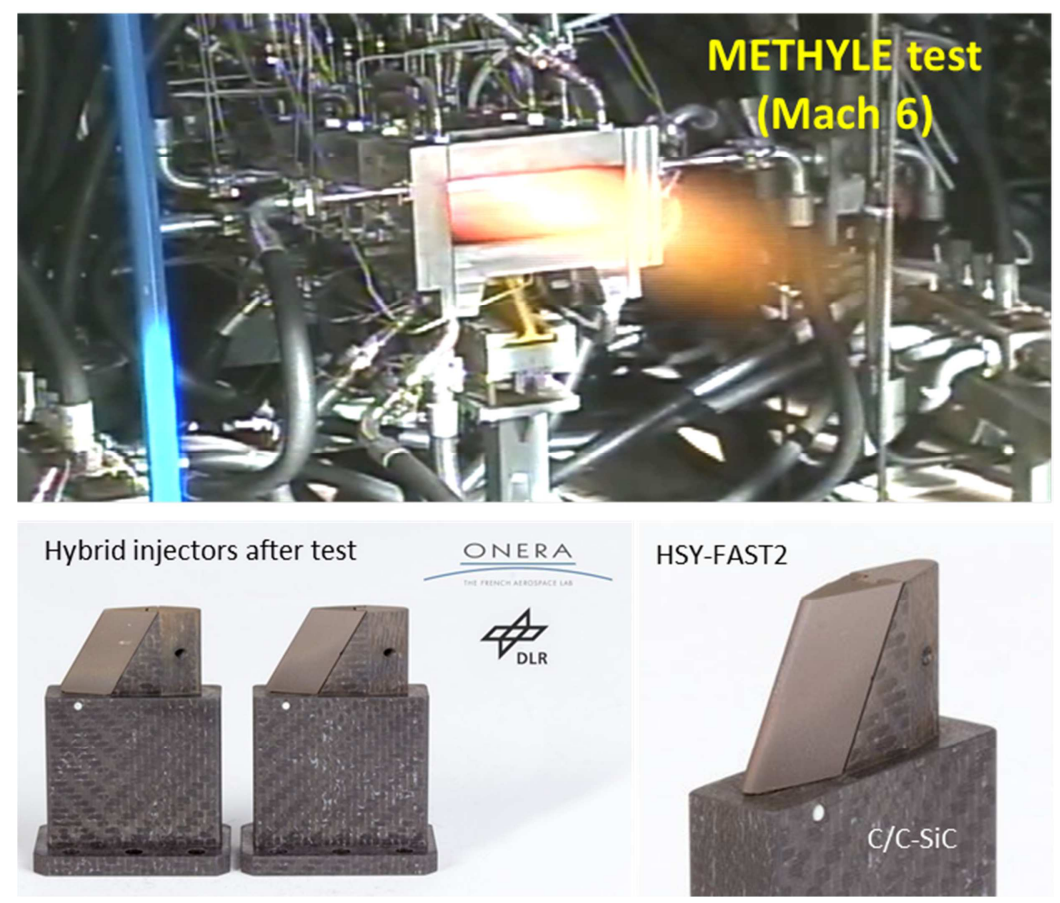

Fig 7. METHYLE facility during test at Mach 6 and aspect of the hybrid injectors after the test campaign

As we can see on the pictures of the Fig 7 but also by analysing others parameters observed during the test (surface temperature in particular), the results are very promising. There are just some traces of the flux on the external surfaces of the injectors. So, despite the fact that an assessment of monolithic UHTCs in realistic combustion environment was really challenging, excellent results have 
been obtained. Thus, the capabilities of thin uncooled UHTC injectors $(R=1 \mathrm{~mm})$ to sustain a severe and long test in combustion environment has been demonstrated.

Therefore, thanks to a fruitful collaborative work achieved notably with $M$. Kuhn from DLR and M. Bouchez from MBDA, hybrid injectors made of UHTC and CMC have been successfully tested in relevant conditions. This success is particularly promising and it paves the way for new realisations (optimised uncooled injectors, fins, rudders, nozzles ...).

\section{Conclusions and perspectives}

Hypersonic and propulsion applications provide some unique thermal-structural challenges (sharp leading edges, air intakes, uncooled injectors, etc.). In order to fulfil the requirements of these components, some specific materials seem to be compulsory: UHTCs. Indeed, thanks to their unique combination of mechanical, thermal and chemical properties, UHTCs are a promising technology for use in a number of high temperature structural applications.

In this context, for more than a decade, Onera has been involved in several studies. Most of the work has been focused on monolithic ceramics and further programs are still engaged on this way. Indeed, thanks to a new high capacity sintering facility received this year (DCS 200-40 from Thermal Technology LLC), several projects to increase UHTC monolithic properties and their potential uses will begin very soon. Moreover, the demonstration of their ability to fulfil the requirements of ramjet combustor environment is a base to build new projects for more efficient propulsion components.

However, for some structural applications, their toughness performance is not sufficient. That's why a good part of the work recently achieved has been focalised on the development of UHTCMC by a slurry infiltration process. First results are encouraging but some improvements are still necessary to optimise their densification (several infiltrations, new infiltrations parameters, finer powder grain size, new raw materials ...). Indeed, this is the best way to improve their mechanical properties but also to increase their global performances (oxidation resistance notably).

\section{Acknowledgment}

A good part of this work was carried out within two projects investigating high-speed transport: "Aerodynamic and Thermal Load Interactions with Lightweight Advanced Materials for High Speed Flight" and "Aero-Thermodynamic Loads on Lightweight Advanced Structures II". These studies are coordinated by ESA-ESTEC and supported by the EU within the 6th and 7th Framework Programmes. 


\section{References}

1. M.M. OPEKA, I.G. TALMY, J.A. ZAYKOSKI - Oxidation-Based Materials Selection for $2000^{\circ} \mathrm{C}+$ Hypersonic Aerosurfaces: Theoretical Considerations and Historical Experience. Journal of Materials Science 39, 5887-5904, (2004).

2. F. MONTEVERDE, A. BELLOSI, L. SCATTEIA - Processing and properties of ultra-high temperature ceramics for space applications. Mater. Sci. Eng. A 485, 415-421 (2008).

3. T. H. SQUIRE, J. MARSCHALL - Material Property Requirements for Analysis and Design of UHTC Components in Hypersonic Applications. J. Eur. Ceram. Soc., 30 [11] 2239-51 (2010).

4. P. A, JAYASEELAN and al. - UHTC composites for hypersonic applications. J. Am. Ceram. Soc., 91, 22-29 (2012)

5. W. G. FAHRENHOLTZ, E. J. WUCHINA, W.E. LEE, Y. ZHOU - Ultra-High Temperature Ceramics: Materials for Extreme Environment Applications (2014).

6. J.F. JUSTIN - Investigations of High Temperature Ceramics for Sharp Leading Edges or Air Intakes of Hypersonic Vehicles. $3^{\text {rd }}$ EUCASS, Versailles, France, CD-ROM ISBN 978-2-930389-478, (2009).

7. J.F. JUSTIN and A. JANKOWIAK - Ultra High Temperature Ceramics: Densification, Properties and Thermal Stability. AerospaceLab, issue 3 - November 2011.

8. M. BOUCHEZ and al. - Combustor and Material Integration for high speed aircraft in the European research Program ATLLAS 2 (American Institute of Aeronautics and Astronautics, 2014). doi:10.2514/6.2014-2950

9. M. KUHN and al. - Ceramic Strut Injection Technologies for High-Speed Flight. (American Institute of Aeronautics and Astronautics, 2017). doi:10.2514/6.2017-2416

10. J. STEELANT and al. - Achievements obtained within ATLLAS II on Aero-Thermal Loaded Material Investigations for High-Speed Vehicles (21st AIAA International Space Planes and Hypersonics Technologies Conference, Xiamen, China, (AIAA 2017-2393), doi:10.2514/6.2017-2393

11. V. GUERINEAU - Mécanismes et cinétiques d'oxydation de matériaux ultraréfractaires sous conditions extrêmes. Ph.D. Dissertation of Pierre et Marie Curie University (2017)

12. V. GUERINEAU, A. JULIAN-JANKOWIAK - Oxidation mechanisms under water vapour conditions of $\mathrm{ZrB}_{2}-\mathrm{SiC}$ and $\mathrm{HfB}_{2}-\mathrm{SiC}$ based materials up to $2400^{\circ} \mathrm{C}$. J. Eur. Ceram. Soc. 38, 421-432 (2018).

13. S-Q. GUO - Densification of $\mathrm{ZrB}_{2}$-based composites and their mechanical and physical properties: a review. J Eur Ceram Soc ;29 (6):995-1011, (2009).

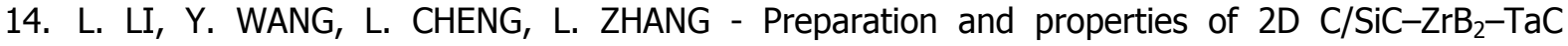
composites. Ceram. Int. 37, 891-896 (2011)

15. S. ZHANG, S. WANG, Y. ZHU, Z. CHEN - Fabrication of ZrB ${ }_{2}$-ZrC-based composites by reactive melt infiltration at relative low temperature. Scripta Materialia. 65, 139-142 (2011).

16. A. PAUL, S. VENUGOPAL, J. BINNER and al. - UHTC-Carbon fibre composites: Preparation, oxyacetylene torch testing and characterisation. J. Eur. Ceram. Soc. 33, 423-432 (2013)

17. L. SILVESTRONI, D.D. FABBRICHE, D. SCITI - Tyranno SA3 fiber-ZrB ${ }_{2}$ composites. Part I: Microstructure and densification. Materials \& Design, 65, 1253-1263 (2015)

18. M. KÜTEMEYER, L. SCHOMER, T. HELMREICH, S. ROSIWAL, D. KOCH - Fabrication of ultra high temperature ceramic matrix composites using a reactive melt infiltration process. J. Eur. Ceram. Soc 36, 3647-3655 (2016)

19. S. TANG, C. HU - Design, Preparation and Properties of Carbon Fiber Reinforced Ultra-High Temperature Ceramic Composites for Aerospace Applications: A Review. J. of Materials Science \& Technology, 33, 117-130 (2017)

20. Q. LI, S. DONG, Z. WANG, G. SHI - Fabrication and properties of 3-D $C_{f} / Z r B_{2}-Z r C-S i C$ composites via polymer infiltration and pyrolysis. Ceramics International, 39, 5937-5941 (2013)

21. ASTM Standard E1876-09 - Standard Test Method for Dynamic Young's Modulus, Shear Modulus, and Poisson's Ratio by Impulse Excitation of Vibration

22. G.R. ANSTIS and al - A critical evaluation of indentation techniques for measuring fracture toughness: I . direct crack measurements, J. American Ceramic Society, 64, 534-553 (1981)

23. A. GÜLHAN, B. ESSER - Arc-Heated Facilities as a Tool to Study Aerothermodynamic Problems of Reentry Vehicles. Progress in Astronautics and Aeronautics, Vol. 198, AIAA, 375-403 (2002)

24. F. FALEMPIN, J.P. MINARD - METHYLE - A new long endurance test facility for dual-mode ramjet technologies. AIAA-2006-2650, Hypersonic technologies conference, Dayton, USA (2008) 